\title{
Gender Discrimination in Sports: Depleting Respect of Women Players in India
}

\author{
Dr. Deepti Kohli \\ Associate Professor, Vivekananda Institute of Professional Studies, Law School
}

\begin{abstract}
Gender ratio in sports is highly skewed in India, which has left the female participation in sports as marginal and deficient. So far only five women from the country have brought home the Olympics medals. There are several constraints which are more applicable to women than men in sports. To name some, the meager stipend paid to sports women as compared to men, biasness in receiving sports awards, the lack of women coaches, absence of family support or the issues related to sexual harassment, etc. Some more of such issues have put the condition of women players in dearth. In this paper an attempt has been made to analyze the deteriorating condition of women players under grey areas and the need for the implementation of sports law.
\end{abstract}

Keywords: Gender Pay Gap, Biasness in Awards, Dearth of Women Coaches, Sexual Harassment, Role of Media

\section{Introduction}

Sport as a 'gendered arena' is almost a truism. A large number of women are discriminated against men in majority of sports.[1] The two ways of understanding this gendered arena are, the statistical inadequacy of literature on women's participation in sports, and second, the way sports created gender subjectivity. There is a very little mention of women players or women's clubs in historical and sociological research on sport in India. Media has also played a pivotal role in widening the gap of gender discrimination in sports. Numerous examples can be sited to portray the deplorable state of affairs of women players in India. For example, Sania Mirza, was criticized by some muslim religious groups, for wearing women's tennis attire which is not suited to Islam. The gymnast Dipa Karmakar was not allowed to take her personal physio to Olympic Games at Rio, before she staggered the world by qualifying for the finals. The Squash Rackets Federation of India, didn't recommended name of Dipika Pallikal for the Arjuna Award, even after she become the first Indian in world Top 15 rank. Similarly, Sania Nehwal was not recommended for Padma Bhushan by the sports ministry, when they recommended Sushil kumar for the same award in 2015. As per the sportsperson-turned-politician and former Lok Sabha MP Jyotirmoyee Sikdar, who won two golds and one silver medal in the 1998 Bangkok Asian Games, 'If a woman player does well, her husband becomes a coach and is conferred a Dronacharya award.'[2] Apart from this in various incidents, women players have been sexually abused by their male coaches or by the authorities of federations.[3]

\section{Gender pay gap}

Apart many of the challenges that women faces in sports, pay gap is the most predominant. This pay gap is evident in various studies and reports. For example, tennis players Serena Williams and Maria Sharapova are shown at the $40^{\text {th }}$ and $88^{\text {th }}$ rank respectively, in the list of highest paid players in 2016. [4] This happens when the men and women play in a discipline that has same prize money. The highest paid male athlete was made 10.1 times as much as the highest paid female athlete.[5] In India, the gender pay gap across all the sectors is 25\%.[6] Earlier BCCI did not even provided job security to the women cricketers, where the male cricketers had their salaries running to several lakhs. During World Twenty 20 competitions, the International Cricket Council funded all the men's teams to fly business class, but only paid for the women's teams to fly economy class. In 2016, women cricketers were granted central contract.[7] where again the lucrative amount was lesser as compared to what male cricketers get.[8]

In 2017, the average season pay of the National Basketball Association for male was, \$7,147,217 which was 96 times than the Women's National Basketball Association, who received only US\$ 74,759.[9] According to a very recent survey, the gender pay gap in sports is larger than one finds in politics, academia, business and medicine.[10]

Gender Prize Money Gap has also contributed towards the increasing gender discrimination against women player. Table 1 covers the variation in prize money of some most prominent sports.[11]

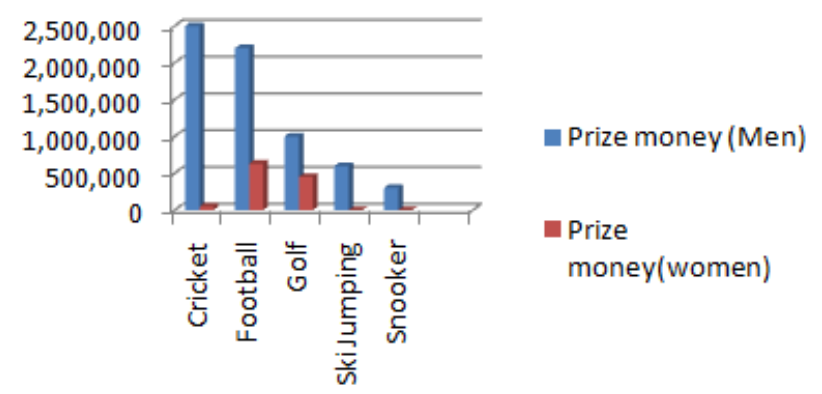

Table 1

A very recent study commissioned for Women Sports Week, states that $83 \%$ of sports now reward men and women equally; however, disparity still persists in cricket, football and golf. In the ICC Women's World Cup there was a 10fold increase in the prize money from $£ 150,000$ to $£ 1.5 \mathrm{~m}$. But the winning men's team at the 2019 World Cup would still be awarded six times the prize money, i.e. £3.1m.[12] Similarly in football the men gets $£ 22 \mathrm{~m}$ whereas the women only receives $£ 630,000$. In golf, the prize money for men is $£ 1.1 \mathrm{~m}$ as compared to $£ 212,000$ which women receives.[11]

\section{Biasness in awards}

\section{Volume 6 Issue 12, December 2017}




\section{International Journal of Science and Research (IJSR) \\ ISSN (Online): 2319-7064}

Index Copernicus Value (2016): 79.57 | Impact Factor (2015): 6.391

In India there are four categories of sports awards. Rajiv Gandhi Khel Ratna Awards, Arjuna Awards, Dhyan Chand Awards are given for the exemplary performance by the sportsperson in various events. Dronacharya Award is presented for the brilliance in sports coaching. There is, however, a gender gap prevalent in the awards also. According to a recent study of 2016, there is a huge gap in the recipient of these awardees since the inception of these awards.[13]

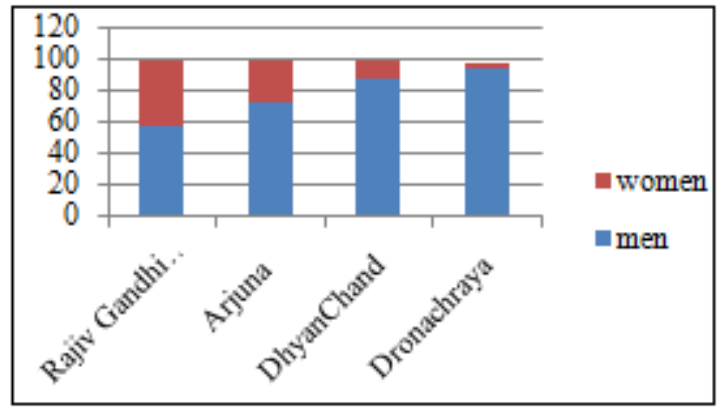

Table 2

As shown in Table 2, the Rajiv Gandhi Khel Ratna Awards has still maintained a parity with $58.6 \%$ awards for men and $41.40 \%$ for women. The Arjuna Awards on the other hand, have merely one-third women awardees, with $73.3 \%$ awards for men and only $26.70 \%$ awards for women. The gap is further prevalent is Dhyan Chand Awards with $88.6 \%$ men recipients and $11.4 \%$ women recipients. Dronacharya Awards are totally man's bastion with $95.4 \%$ as against only $4.60 \%$ of women awardees, which is also one of the basic reasons for the lack of female coaches in India.

The number of awards by the government for each year is limited and they are often given on the recommendation from the sports federations. But the plight of these federations is that they are male dominated.

Yet there is another factor for fewer sports awards for women, and it is their low participation in certain sports. The participation of women for sports such as athletics is closer to $40 \%$, but it drops to $10 \%$ when it comes to sports such as boxing and wrestling.[14]

\section{Lack of Women Coaches}

Sports is one of the most visible and powerful social institutions in the world. Individuals who are seen and known in the world of sports, like coaches, who communicate; who and what is relevant and valued, and a majority of the time in every country in the world, those coaches are men.[15]

Another account of gender discrimination in sports is evident from the negligible number of women coaches. The administration, sports federations and coaching centres are male dominated. The women, if appointed in the sports federations, are expected to tackle the growing complaints of sexual assaults in Indian sports bodies. Many women coaches found this offensive since many a times their worth was seen only as security guards for the protection of women athletes and nothing more.[16]
According to a report, almost half of the National Olympic Committees surveyed by the International Olympic Committee, have fewer than $20 \%$ of women on their Executive Boards, including 10 nations who had no women at all.[17] In Indian sports association governing bodies, women constitute only $2.8 \%$ in all. Very few female coaches who could manage to make their names in female coaches includes Sunil Dabas, the only woman coach to be given a Padma Shri in India; Nikki Ponappa, Golf coach; Simi Begam Sharma, Tennis coach. Female coaches also suffer opposition from their families as it is not considered safe to travel as a girl. Sometimes female coaches are replaced without affording any valid reason. Purnima Rao, the coach of ICC Women's Cricket World Cup was replaced by a former Baroda Batsman, when the team was already giving good results and was reported to be in the winning form.[16]

In the west Title IX of US has been criticized for an unexpected and steady decline of female coaches from 90 percent in 1972 to 43 percent in 2014. Title IX, 1972 is a landmark legislation which prohibited discrimination on the basis of sex in all educational programs. In response to Title IX, many colleges combined male and female athletic departments, whereby the men slowly and gradually were selected for female team players. Title IX also provides for pay parity for women's-team coaches, but the lucrative salaries attract male coaches to female sports. These phenomena, among others, pushed women out of collegiate coaching.[18]

Sports calls for equal representation of men and women in all forms, be it playing games or being prospective coaches for those games. Scholars have carved out differences in coaching techniques of male and female coaches.[19] The differences, however, should not jeopardize the interest of any community, economically or otherwise.

\section{Sexual Harassment}

One of the major reasons for depleting respect for female players in all the countries is that they are often seen as a sex object. They are subjected to sexual harassment. Broadly sexual harassment includes a wide range of behaviors i.e., unwelcome sexual advances, requests for sexual favors, and other verbal or physical conduct of a sexual nature, when submission to or rejection of this conduct explicitly or implicitly affects an individual's performance in Sports, unreasonably favour to an individual's to select in the team's performance or creates an intimidating, hostile or offensive work environment for granting undue favour for including in a team to a weaker sex.

Many females drop out of sport rather than continue being subjected to the constant harassment and abuse. It has been found that very few instances of sexual harassment gets reported.

In one of the incident obscene printed messages, signed by the sports authority, were pasted in four places in the restroom that asked female athletes to masturbate before practice.[20] In another case a minor and budding tennis player committed suicide after repeated molestation by the DGP. The accused was convicted for a rigorous conviction

\section{Volume 6 Issue 12, December 2017}




\section{International Journal of Science and Research (IJSR) \\ ISSN (Online): 2319-7064}

Index Copernicus Value (2016): 79.57 | Impact Factor (2015): 6.391

of eighteen months, but was released after five months only.[21] The reason given in the judgment stated that, because the accused was of old age and was suffering from, health ailments, he further had responsibility of looking after the unmarried daughter suffering from congenital heart disease, and also because of his past meritorious service and prolonged trial, the court didn't thought it expedient to put him back to jail.[22]

In a similar event, a brilliant kabbadi player who had represented India at several international events lost her life merely because she refused to share her mobile number with a CRPF jawan.[23]

Role played by sports authorities is very negligible. Sports Authority of India has set out its aims and objectives. Out of several objectives, one of them is prevention of sexual harassment of women in sports. So far there have been two reported cases where coaches were arrested on the charges of molestation and sexual assault, with a very minimum amount of conviction, for eg., three days.[24] The Sports Law \& Welfare Association of India (SLAWIN), though, has made provision for harassment in sports, but has never reported any incident. National Sports Policy, under the ministry of Youth Affairs and Sports, only provides for lodging an online complaint.[25] But does not provide for any viable data whereby it can be traced as to how many complaints have been filed in sexual harassment cases, in how many cases they have ever adjudicated upon with conviction.

\subsection{Draft National Sports Development Bill, 2013}

The only legislation that we have for sports is Draft National Sports Development Bill, 2013.[26] The only quandary is that it has not seen the light of the day. It is still a draft which is under consideration. If it could be given legal recognition, much could be done for benefitting the women in sports. Some of the key features of this draft related to sexual harassment are discussed here.

It provides for the elimination of sexual harassment in sports under chapter IV part C, where it has been made a duty of every National Sports Federation, the National Olympic Committee, the Sports Authority of India and other sports bodies to prevent sexual harassment in sports.

The measures that can be adopted includes;-

a) Notifying, publishing and circulating, guidelines

b) Establishing appropriate systems to ensure healthy relationship between coach and athletes;

c) Providing for sufficient number of women members in the coaching and support staff for every woman athlete or team of women athletes;

d) Providing appropriate conditions for women in respect of work, leisure, health and hygiene;

e) Providing reasonable assistance to the adversely affected athlete, where sexual harassment occurs as a result of an act or omission by any third party and initiate appropriate legal action against such third party;

f) To set up a complaints committee for redressal of the complaints in a time bound manner.
In order to prevent the possibility of any undue pressure or influence from within the organization, the complaints committee would have an independent member either from a non-governmental organization or other body/person, as the case may be, who would be familiar with the issues of sexual harassment.

It also provides for the penalty, in the form of debarring by the National Olympic Committee and National Sports Federations from participating, in any existing or future sports event in any capacity, whether as an Office Bearer of any sports federation or sports committee or a manager or coach or athlete or otherwise.[27]

Therefore, our policy makers should adopt this bill and implement it for the future prospects of women sport players.

\section{Role of Media}

Does media also plays any role in the deviating condition of women players? It has been found that in spite of the monumental achievements by the female players as a whole, the way in which they are presented in the media remains drastically different than the way their male counterparts are portrayed. The role of media can be criticized on mainly for the language they used for men and women, and secondly for the lesser amount of coverage given to the women players.

\subsection{Language used to describe athletes in the media}

Media generally target women and not men with the words such as 'aged', 'older', 'married' or 'unmarried'. The words used for men in sports are 'fastest,' 'strong,' 'big,' 'real,' and 'great'. A recent study shows that women get less airtime than men, and that their physical appearance and personal lives are frequently mentioned by the media. The below mentioned data shows gender divides in the language of sport, by the media.[28]

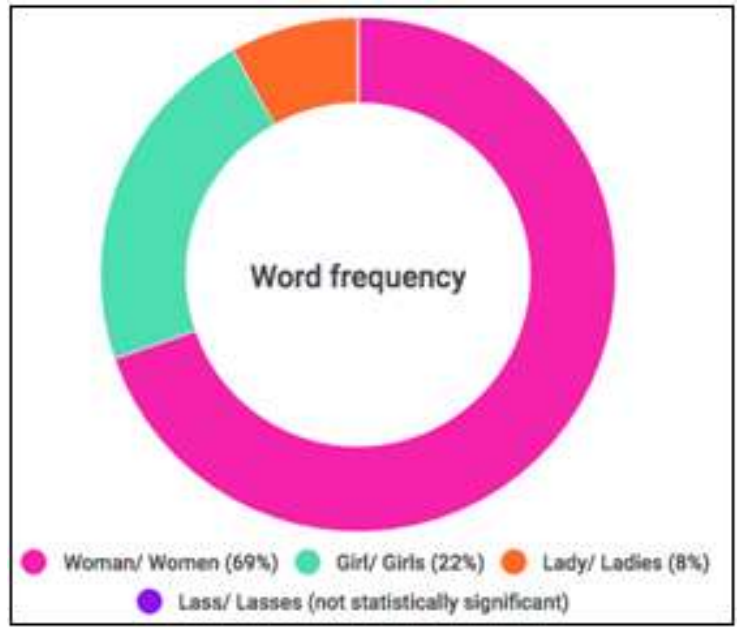

Words used to describe women Doughnut 1

Volume 6 Issue 12, December 2017 www.ijsr.net 


\section{International Journal of Science and Research (IJSR) \\ ISSN (Online): 2319-7064}

Index Copernicus Value (2016): 79.57 | Impact Factor (2015): 6.391

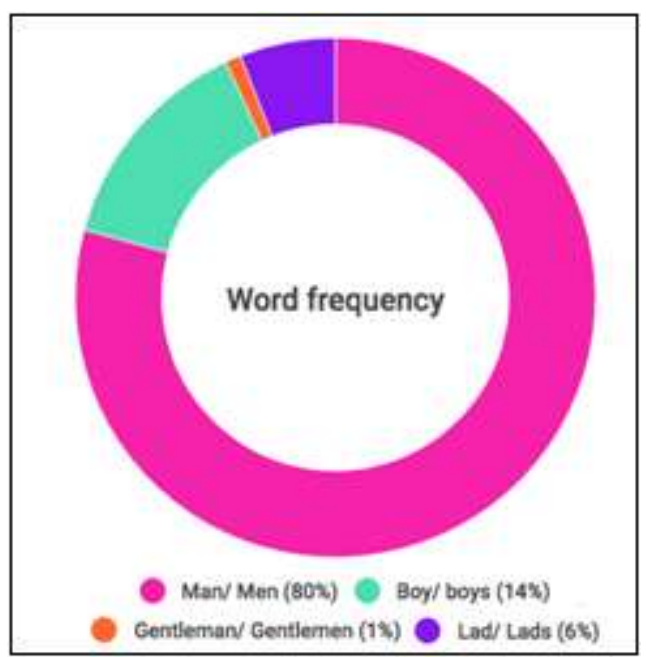

Words used to describe men

\section{Doughnut 2}

Such subtle gender biases in language used by media are common far beyond the world of sports.

\subsection{Less coverage to women}

In the Rio Olympics, the media featured 169 events for men and 137 for women. It was taken as men would walk away with more than $55 \%$ of the gold, silver and bronze medallions.[29]

Another study of two English newspapers in India in their coverage of the 2014 Incheon Asian games, indicated women as second class citizen, who were less deserving of coverage than male counterparts. The females were depicted more as feminine, glamorous and off-the field avatars rather than as hardened athletes. Sarita Devi, boxer, did not get coverage because she won multiple gold medals but because she complained of unfair rules. The photographs showed her crying with her husband.

When Sania Mirza won the mixed doubles gold in Tennis and a medal in the ladies singles, none of the photographs in either newspaper showed her in action on court. Mid-Day, however, carried one photograph of her posing with the trophy and another where she was off court, attending a fashion show.[30]

Three times World champion boxer Mary Kom won gold, but her news became prominent only when a Bollywood movie featuring Priyanaka Chopra was made on her life. Still the photographs carried the image of actress Priyanka Chopra, one image of Mary Kom with her husband and children. Geeta Phogat, female wrestler and gold medalist, states that when she won the gold medal at the Commonwealth Games in Delhi in 2010, she didn't get recognized the way she got recognition after the release of bollywood movie 'Dangal' in 2016.[31]

According to the Women's Sports Foundation, approximately 40 percent of sport and physical activity participants are women, only 6 to 8 percent of total media sports coverage is devoted to them. Further in a study of four major newspapers; USA Today, the Boston Globe, the
Orange County Register and the Dallas Morning news, women-only sports stories totaled just 3.5 percent of all sports stories.[32]

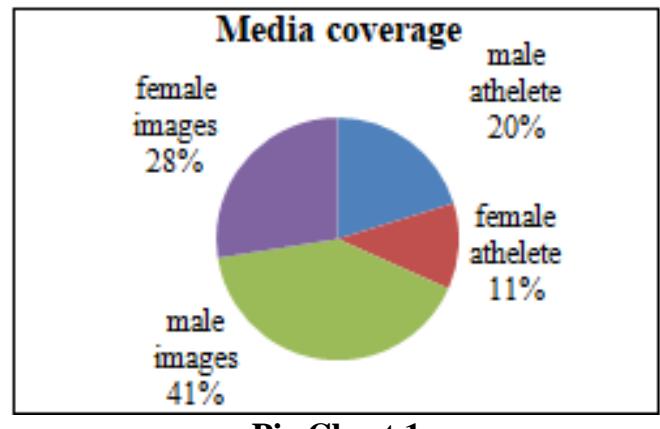

Pie Chart 1

Another study of on the two newspapers, Mid-Day's and Telegraph's coverage of the Asian games 2014 reveals that out of 53 male and 30 female athletes, the media coverage on front page of male athlete was of 107 images which was alarmingly higher than merely 72 images of female athletes.[30] The Pie Chart 1 shows the figures in percentages.

Another study by The Women's Sport and Fitness Foundation (WSFF)[33] reveals that only $7 \%$ of sports media coverage is devoted to women's sport and just $0.4 \%$ of commercial investment goes to women only sport and over $60 \%$ goes to men's.

\section{Conclusion}

Gender discrimination in sports is predominantly man made. There is no sport where women have not competed with their male counterparts. Still we have seen a lot of disparity when it comes to unequal pay for men and women for equal sport events; or discrimination in the amount of prize money and the biasness in awards. It is probably one of the major reasons for the dearth of female coaches in India. There have been many reported incidents of sexual harassment against women players. A special role has been played by media in overshadowing the female players by the victorious men's. And many such reasons have contributed towards less participation of females in sports.

Both men and women can bring more laurels to India with a little encouragement and better gender parity. It is not the parents that are not letting girls play but it is the system of Indian sport that is to blame. Though many policies have been adopted by the government so far for the proper management of sports but the lacunae is highly apparent. It is high time that Draft National Sports Development Bill, 2013 would be given legal sanctity.

Our constitution mandates the state responsibility for the smooth and proper functioning of sport system in India. It is now the accountability of the government to implement the sports laws strictly. If it would be done, the days are not far when Indian women would take lead in all sport events in majority.

\section{Volume 6 Issue 12, December 2017}




\section{International Journal of Science and Research (IJSR) \\ ISSN (Online): 2319-7064}

Index Copernicus Value (2016): 79.57 | Impact Factor (2015): 6.391

\section{References}

[1] Kevin Young, Sociology of Sport: A Global Sub discipline in Review, Emerald Group Publishing, 2016 p 49.

[2] India's sports awards have a palpable gender bias: Gender bias in promoting sporting talent might be holding back India's performance on the big stage; http://www.livemint.com/Opinion/gFXCC5dLy0yT3Zs RRVwxUK/Indias-sports-awards-have-a-palpablegender-bias.html (accessed on $7^{\text {th }}$ December 2017)

[3] India 2014: A Reference Annual, Publications Division, Ministry of Information and Broadcasting, Government of India, 2014, p 936.

[4] Forbes, The World's Highest Paid Athletes, 2016, https://www.forbes.com/athletes/\#3cc9b30b55ae (accessed on $8^{\text {th }}$ December 2017)

[5] ibid

[6] 'Women of India Inc', Monster Salary Index (MSI) report on gender pay parity, March 2017, http://media.monsterindia.com/ (accessed on $8^{\text {th }}$ December 2017)

[7] Indian Cricketers Salaries 2017-18, July 2017, www.totalsportek.com/cricket/indian-player-salariescentral-contracts-2015/ (accessed on $8^{\text {th }}$ December 2017)

[8] ibid

[9] Introducing-The Summit WNBA salaries database https://summitthoops.com/2017/08/28/wnba-salariesdatabase/ (accessed on $7^{\text {th }}$ December 2017)

[10] The Gender (In)Equality Issue, Global Sports Salaries Survey, November 2017, http://globalsportssalaries.com/GSSS\%202017.pdf (accessed on $8^{\text {th }}$ December 2017)

[11] Prize money in sport - BBC Sport study 2014 http://www.bbc.com/news/uk-29665693 (accessed on $9^{\text {th }}$ December 2017)

[12] Women's Sports Week, 2017 https://www.womeninsport.org/wsw2017/ (accessed on $11^{\text {th }}$ December 2017)

[13]Ministry of Youth Affairs and Sports https://yas.nic.in/youth-affairs/awards (accessed on $20^{\text {th }}$ December 2017)

[14] India's sports awards have a palpable gender bias http://www.livemint.com/Opinion/gFXCC5dLy0yT3Zs RRVwxUK/Indias-sports-awards-have-a-palpablegender-bias.html (accessed on $20^{\text {th }}$ December 2017)

[15] Nicole M. LaVoi, Women in Sports Coaching, Routledge,

2016.

https://books.google.co.in/books/about/Women_in_Spor ts_Coaching.html?id=ZWCpCwAAQBAJ\&redir_esc=y (accessed on $20^{\text {th }}$ December 2017)

[16] Could the future of sports coaching in India ever be female? http://indianexpress.com/article/sports/ (accesses on $12^{\text {th }}$ December 2017)

[17] Factsheet Women In The Olympic Movement Update January 2016

https://stillmed.olympic.org/Documents/Reference_doc uments_Factsheets/Women_in_Olympic_Movement.pd $f\left(\right.$ accessed on $16^{\text {th }}$ December 2017)

[18] https://www.theatlantic.com/education/archive/2017/07/ the-field-where-men-still-call-the-shots/535167/ (accessed on $11^{\text {th }}$ December 2017)
[19]Coaching Women:Developing Female Coaches https://www.womeninsport.org/wp-

content/uploads/2015/04/Developing-FemaleCoaches.pdf (accessed on $16^{\text {th }}$ December 2017)

[20]Dirty message greets female athletes at Kanteerava stadium

https://timesofindia.indiatimes.com/city/bengaluru/Dirty -message-greets-femaleathletes-at-Kanteerava

stadium/articleshow/55946081.cms $\quad\left(\right.$ accessed on $17^{\text {th }}$ December 2017)

[21][21] Ruchika molestation case: SC upholds former Haryana DGP Rathore's conviction, but reduces his jail term https://timesofindia.indiatimes.com/india/Ruchikamolestation-case-SC-upholds-former-Haryana-DGP-

Rathores-conviction-but-reduces-his-jail term/articleshow/54476446.cms (accessed on $17^{\text {th }}$ December 2017)

[22] S.P.S. Rathore v. C.B.I., 2016 SCC Online SC 985

[23]CRPF jawan shoots national-level Kabaddi player https://www.ndtv.com/video/news/news/crpf-jawanshoots-national-level-kabaddi-player-190572 (accessed on $17^{\text {th }}$ December 2017)

[24] Sports Authority of India coach apprehended on charges of sexual assault https://www.sportskeeda.com/athletics/sports-authorityindia-coach-apprehended-charges-sexual-assault Sports Authority of India coach arrested on molestation charges

https://www.youtube.com/watch?v=RWUNEZKCPHQ (accessed on $17^{\text {th }}$ December 2017)

[25]Ministry of Youth Affairs and Sports https://rtionline.gov.in/guidelines.php?request (accessed on $17^{\text {th }}$ December 2017)

[26] The National Sports Development Bill, 2013https://yas.nic.in/sites/default/files/File921.pdf (accessed on $17^{\text {th }}$ December 2017)

[27] id Chapter X, Section 44.

[28] Aesthetics, athletics and the Olympics, Cambridge University Press, http://www.cambridge.org/aboutus/news/aest/ (accessed on $18^{\text {th }}$ December 2017)

[29] Women, Media Bias And The Olympics, https://www.huffingtonpost.com/samantha_levine/women-media-bias-and-the-_b_11459540.html (accessed on $18^{\text {th }}$ December 2017 )

[30] Chattopadhyay Dhiman, Gender bias in India's newspaper coverage of male and female athletes at the 2014 Incheon Asian Games, Global Media Journal, Indian Edition, vol. 7, 2017

[31] Geeta Phogat says 'Dangal' made her more famous than Commonwealth gold https://economictimes.indiatimes.com/magazines/panac he/geeta-phogat-says-dangal-made-her-more-famousthan-her-commonwealth-gold$\mathrm{did} /$ articleshow/57384502.cms $\quad$ (accessed on $19^{\text {th }}$ December 2017)

[32] Gender Discrimination in Sports, https://www.livestrong.com/article/247625-genderdiscrimination-in-sports/ (accessed on $19^{\text {th }}$ December 2017)

[33] The Women's Sport and Fitness Foundation http://www.wsff.org.uk/the-challenge/the-challengeelite-sportswomen/index.html (accessed on $20^{\text {th }}$ December 2017) 